\title{
Occurrence of Caligus asperimanus Pearse, 1951 (Copepoda: Caligidae) parasitic Lutjanus spp. (Perciformes: Lutjanidae) in the western South Atlantic
}

\author{
Ocorrência de Caligus asperimanus Pearse, 1951 (Copepoda: Caligidae) \\ parasitos de Lutjanus spp. (Perciformes: Lutjanidae) no Atlântico Sul ocidental \\ Bruno De Laquila Oliveira1* (1); Luiz Fernando Loureiro Fernandes²; Gustavo Martins Rocha; \\ Ana Cecilia Gomes Silva Malanski³; Fabiano Paschoal ${ }^{4}$
}

\author{
${ }^{1}$ Programa de Pós-graduação em Oceanografia Ambiental, Base Oceanográfica, Universidade Federal do Espírito Santo - UFES, \\ Aracruz, ES, Brasil \\ ${ }^{2}$ Departamento de Oceanografia e Ecologia, Universidade Federal do Espírito Santo - UFES, Vitória, ES, Brasil \\ ${ }^{3}$ Laboratório de Cultivo de Organismos Marinhos, Universidade Federal do Espírito Santo - UFES, Aracruz, ES, Brasil \\ ${ }^{4}$ Laboratório de Parasitologia Animal, Centro de Pesquisa em Biologia - CEPBio, Universidade Castelo Branco-RJ, Realengo, RJ, Brasil
}

How to cite: Oliveira BL, Fernandes LFL, Rocha GM, Malanski ACGS, Paschoal F. Occurrence of Caligus asperimanus Pearse, 1951 (Copepoda: Caligidae) parasitic Lutjanus spp. (Perciformes: Lutjanidae) in the western South Atlantic. Braz J Vet Parasitol 2020; 29(2): e018219. https://doi.org/10.1590/S1984-29612020001

\begin{abstract}
Sea lice are widespread copepods in marine teleost around the world. In this paper the first record of Caligus asperimanus Pearse, 1951 in the Western South Atlantic is documented parasitizing Lutjanus jocu and Lutjanus vivanus caught from coastal zones of Espírito Santo and Rio de Janeiro State, respectively.
\end{abstract}

Keywords: Lutjanus vivanus, Lutjanus jocu, ectoparasites, infestation, South Atlantic.

\section{Resumo}

Os piolhos marinhos são copépodes abrangentemente relatados em teleósteos marinhos ao redor do mundo. Neste estudo, é documentado o primeiro registro de Caligus asperimanus Pearse, 1951, no Atlântico Sul Ocidental, parasitando Lutjanus jocu e Lutjanus vivanus capturados nas zonas costeiras do Espírito Santo e Rio de Janeiro, respectivamente.

Palavras-chave: Lutjanus vivanus, Lutjanus jocu, ectoparasitos, infestação, Atlântico Sul.

Snappers Lutjanus species (Lutjanidae) can be found in tropical and subtropical waters of the Atlantic, Indian, and Pacific oceans (Nelson et al., 2016). They are a high commercial demand and possess high added value, in addition to hardiness and adaptability in aquaculture, with some well-known species and others being studied in coastal and oceanic regions (Ibarra-Castro \& Duncan, 2007). The dog snapper, Lutjanus jocu Bloch \& Schneider, 1801, and silk snapper, Lutjanus vivanus Cuvier, 1828 are found in continental shelf areas, as well as in clear waters around islands. These species are widely distributed in the Atlantic Ocean from North Carolina (USA) to Southeastern Brazil, feeding day and night on fish, shrimp, crabs, cephalopods, and gastropods (Froese \& Pauly, 2019).

According to Luque \& Poulin (2007), our knowledge about Latin American fish parasite biodiversity is still quite limited, study effort distribution has been quite heterogeneous, and most known fish species have not been examined for parasites.

Members of the Caligidae family are predominantly external fish parasites, inhabiting the external surface, mouth, gills, and opercular cavity of their hosts and comprise one of the most speciose group within the Copepoda, currently encompassing 450 species distributed in 31 genera (Boxshall \& Halsey, 2004; Dojiri \& Ho, 2013). 
The genus Caligus has the largest number of species in its family, comprising more than 250 species, and is also the most widely represented genus in Brazil, totalling 31 species found in the marine environment (Luque et al., 2013). Although the above caligids species have been found on 55 fish species of the Brazilian coast, but there are no records of Caligidae species parasitizing Lutjanidae fish species in Brazilian coast (Luque \& Tavares, 2007; Luque et al., 2013). In the Neotropical Region, Morales-Serna et al. (2016) listed 115 sea lice species found on 217 Neotropical fish species, of which 58 are known Caligus species.

In this study, specimens of Caligus asperimanus Pearse 1951 were collected from two snapper species in Brazil, specifically L. jocu $(n=8)$ caught in the Piraquê-mirim river estuary, Aracruz municipality, Espírito Santo State $\left(19^{\circ} 56^{\prime} \mathrm{S}, 40^{\circ} 10^{\prime} \mathrm{W}\right)$, and $L$. vivanus $(n=2)$ caught off the coast of Rio de Janeiro State $\left(22^{\circ} 55^{\prime} \mathrm{S}, 43^{\circ} 12^{\prime} \mathrm{W}\right)$. Copepods were removed from the fish surface, fixed in $70 \%$ alcohol, and subsequently cleared in a drop of lactophenol before testing with a phase contrast microscope and were examined according to the procedure proposed by Humes \& Gooding (1964). Illustrations were made with the aid of an Olympus CX41 microscope (Olympus Corporation, Tokyo, Japan) equipped with a drawing attachment. Measurements based on nine females are given in millimetres, with the range followed by the mean in parentheses. Representative specimens were deposited in in the scientific collection of the Museum of Zoology, University of São Paulo, Brazil. The scientific and common names of the fish used in the present study were according to Froese \& Pauly (2019).

Based in the morphology of cephalothorax, genital process, abdomen, small appendages and body proportion, specimens of copepods collected in Brazil (Figure 1) corresponds to the description of $C$. asperimanus given by Pearse (1951) and Cressey (1991). A total of nine C. asperimanus female specimens, six on L. jocu (MZUSP No $40232-29$ ) and three on L. vivanus (MZUSP No 40231 - 29), were collected from the hosts. The female copepods $(n=9)$ had a body length of 3.79-4.32 (4.08) mm (excluding caudal rami setae), and all were attached to the external surface of the fish, close to the operculum. No male individuals were found. Female specimens from Brazil are larger $(4.08 \mathrm{~mm})$ than the type specimens collected in Bimini, Bahamas $(3.3 \mathrm{~mm})$, and probably with similar size to the specimens collected in Carrie Bow Cay, Belize (4.42 mm) (Pearse, 1951; Cressey, 1991).
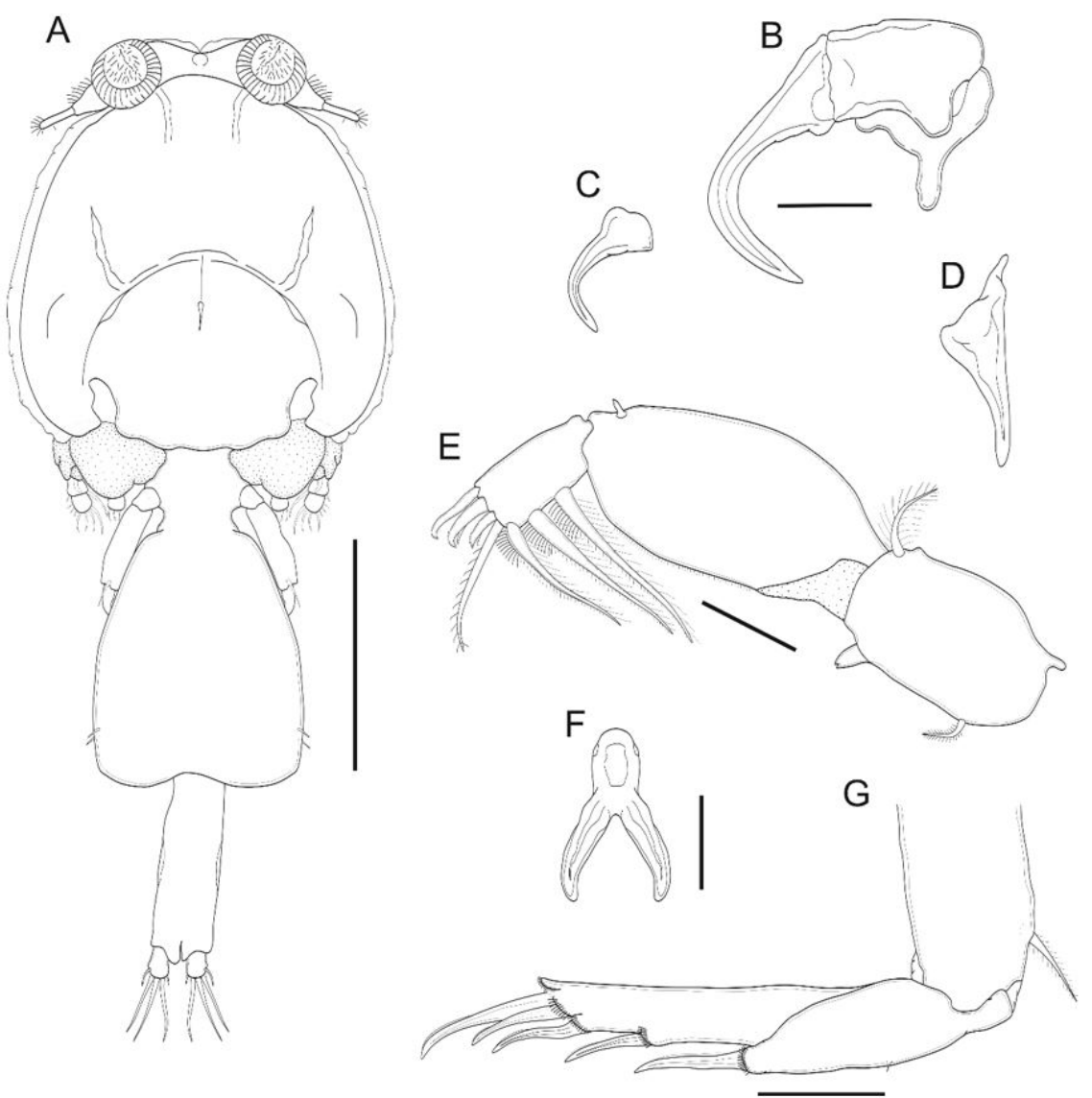

Figure 1. Caligus asperimanus from Brazil. Adult Female. (A) Habitus, dorsal view; (B) Antenna; (C) Postantennal process; (D) Maxillule; (E) Leg 1; (F) Sternal furca; (G) Leg 4. Scale bars: $A=1 \mathrm{~mm}$; B-C and F = $80 \mu \mathrm{m}$; $E$ and $\mathrm{G}=100 \mu \mathrm{m}$. 
Caligus asperimanus was originally described by Pearse (1951) from the mutton snapper Lutjanus analis Cuvier, 1828 (Perciformes, Lutjanidae), collected in the Bimini Sea, Bahamas. This species of ectoparasite was subsequently recorded by Cressey (1991) on schoolmaster snapper Lutjanus apodus Walbaum, 1792, L. jocu, and lane snapper, Lutjanus synagris Linnaeus, 1758, in the Carrie Bow Cay sea, Belize. Years later, Pilla et al. (2012) recorded this species of ectoparasite in John's snapper Lutjanus johnii Bloch, 1792 in the Pacific Ocean for the first time, more specifically from the Indian coast. Although this species of ectoparasite has a high prevalence in snapper fish, recently Morales-Serna et al. (2016), in their study on copepod parasites of economically important Ecuadorian fish, recorded this species for the first time in non-lutjanid fish, i.e., the Chere-chere grunt Haemulon steindachneri Jordan \& Gilbert, 1882 (Haemulidae) and the pacific porgy Calamus brachysomus Lockington, 1880, in addition to the yellow snapper Lutjanus argentiventris Peters, 1869, all from the coastal waters of Jaramijó, Manabí province, Ecuador.

The discovery of $C$. asperimanus in Brazilian waters represents the $32^{\text {nd }}$ Caligus species recorded in the country and the first record of this species of copepod in the western South Atlantic, considerably expanding its geographical distribution. As mentioned in the previous paragraph, this parasitic copepod species has a high incidence in lutjanid fish; however, in this study, C. asperimanus has been recorded for the first time in L. vivanus, being also the first caligid copepod found in snappers in Brazil.

Snapper commercial farming is growing considerably in the Neotropics (Central America and the Caribbean), and several research initiatives are underway in South America and the United States, showing their importance and potential for aquaculture (Castillo-Vargasmachuca et al., 2018). In Brazil, studies with snappers have been developed focused on laboratory reproduction (Fernandes et al., 2012; Sanches et al., 2015), transport (Oliveira et al., 2018) and diets (Sanches, 2011). Appears to be the most suitable for farming in floating cages because it accepts artificial food (pellet), it is easy to manipulate, it tolerates captivity and its growth from hatchery to market size is completed within 8 months (Hernández et al., 2015).

Caligid copepods are a serious problem in European and Asian aquiculture (Boxshall \& Defaye, 1993). According to Johnson et al. (2004), the estimated that in marine and brackish water fish cultures, $61 \%$ of copepod infestations are caused by members of the family Caligidae of which $47 \%$ are caused by species of Caligus, and $14 \%$ by species of Lepeophtheirus. The best-studied examples of this epidemiological interaction are the ectoparasites Caligus elongatus Nordmann, 1832, Caligus rogercresseyi Boxhall \& Bravo, 2000 and Lepeophtheirus salmonis Krøyer, 1837, which can cost the salmon industry, for example, $€ 300$ million (US \$ 480 million) per year and $6 \%$ of the product value (Costello, 2009; Dojiri \& Ho, 2013). The rapid identification and prophylactic actions to eliminate parasitic fauna in fish collected from a natural environment and transported to farming sites (often under high density) are essential for the sanitary control of farmed fish. The threat of sea lice to marine-fish farming should always be considered. Thus, prior knowledge of the parasitic fauna of a possible aquaculture fish is essential, especially in relation to the diagnosis, control, and management of possible parasitic diseases.

\section{Acknowledgements}

To Coordenação de Aperfeiçoamento de Pessoal de Nível Superior (CAPES) - Financing Code 001, for supporting the first author with postgraduate fellowship.

\section{References}

Boxshall GA, Defaye D. Pathogens of wild and farmed fish: sea lice. Chichester: Ellis Horwood; 1993.

Boxshall GA, Halsey SH. An introduction to copepod diversity. London: Ray Society; 2004.

Castillo-Vargasmachuca SG, Ponce-Palafox JT, Arámbul-Muñoz E, Rodríguez-Domínguez G, Aragón-Noriega EA. The spotted rose snapper (Lutjanus guttatus Steindachner 1869) farmed in marine cages: review of growth models. Rev Aquacult 2018; 10(2): 376-384. http://dx.doi.org/10.1111/raq.12166.

Costello MJ. How sea lice from salmon farms may cause wild salmonid declines in Europe and North America and be a threat to fishes elsewhere. Proc R Soc Lond B 2009; 276(1672): 3385-3394. http://dx.doi.org/10.1098/rspb.2009.0771. PMid:19586950.

Cressey RF. Parasitic copepods from the Gulf of Mexico and Caribbean sea, III. Caligus. Smithson Contr Zool 1991; 497(497): 1-53. http://dx.doi.org/10.5479/si.00810282.497. 
Dojiri M, Ho JS. Systematics of the Caligidae, copepods parasitic on marine fishes. Leiden: Brill Publishers; 2013. (Crustaceana Monographs; vol. 18).

Fernandes CAF, Oliveira PGV, Travassos PEP, Hazin FHV. Reproduction of the Brazilian snapper, Lutjanus alexandrei Moura \& Lindeman, 2007 (Perciformes: Lutjanidae), off the northern coast of Pernambuco, Brazil. Neotrop Ichthyo/ 2012; 10 (3): 587-592. http://dx.doi.org/10.1590/S1679-62252012005000022.

Froese R, Pauly D. Epi Info - FishBase: version 04/2019 [online]. Stockholm: FishBase; 2019 [cited 2019 Aug 20]. Available from: http://www.fishbase.org

Hernández C, Ibarra-Castro L, Hernández CH, Quintero-Martínez G, Aragón-Noriega EA, Tacon AG. Growth performance of spotted rose snapper in floating cages and continuous water-flow tank systems. N Am J Aquaculture 2015; 77(4): 423-428. http:// dx.doi.org/10.1080/15222055.2015.1032458.

Humes AG, Gooding RU. A method for studying the external anatomy of copepods. Crustaceana 1964; 6(3): 238-240. http:// dx.doi.org/10.1163/156854064X00650.

Ibarra-Castro L, Duncan NJ. GnRHa-induced spawning of wild-caught spotted rose snapper Lutjanus guttatus. Aquaculture 2007; 272(1-4): 737-746. http://dx.doi.org/10.1016/j.aquaculture.2007.09.007.

Johnson SC, Treasure JW, Bravo S, Nagasawa K, Kabata Z. A review of the impact of parasitic copepods on marine aquaculture. Zoologic Stud 2004; 43(2): 229-243.

Luque JL, Poulin R. Metazoan parasite species richness in Neotropical fishes: hotspots and the geography of biodiversity. Parasitology 2007; 134(6): 865-878. http://dx.doi.org/10.1017/S0031182007002272. PMid:17291392.

Luque JL, Tavares LE. Checklist of Copepoda associated with fishes from Brazil. Zootaxa 2007; 1579(1): 1-39. http://dx.doi. org/10.11646/zootaxa.1579.1.1.

Luque JL, Vieira F, Takemoto R, Pavanelli G, Eiras J. Checklist of Crustacea parasitizing fishes from Brazil. Check List 2013; 9(6): 1449-1470. http://dx.doi.org/10.15560/9.6.1449.

Morales-Serna FN, Medina-Guerrero RM, Fajer-Avila EJ. Sea lice (Copepoda: Caligidae) parasitic on fishes reported from the Neotropical region. Neotrop Biodivers 2016; 2(1): 141-150. http://dx.doi.org/10.1080/23766808.2016.1236313.

NelsonJS, Grande TC, Wilson MV. Fishes of the world. 5th ed. USA:John Wiley \& Sons; 2016. http://dx.doi.org/10.1002/9781119174844

Oliveira BL, Souza RM, Silva JP Fo, Gomes LC, Fernandes LFL. Hematological and biochemical characteristics during the transport of dog snapper Lutjanus jocu (Perciformes: lutjanidae). Neotrop /chthyol 2018; 16(1): e170140. http://dx.doi.org/10.1590/19820224-20170140.

Pearse AS. Parasitic Crustacea from Bimini, Bahamas. Proc Unit Stat Nat Mu 1951; 101(3280): 341-372. http://dx.doi.org/10.5479/ si.00963801.101-3280.341.

Pilla S, Vankara AP, Chikkam V. Copepod parasites of snappers, Lutjanus spp (Pisces, Lutjanidae) with description of a new caligid copepod, Caligus rivulatus sp nov (Copepoda, Caligidae) from Visakhapatnam coast, India. Cibtech J Zool 2012; 1: 16-24.

Sanches EG, Oliveira IR, Serralheiro PCS, Cerqueira VR. Sperm cryopreservation of lane snapper Lutjanus synagris (Linnaeus, 1758). Braz J Biol 2015; 75(3): 662-669. http://dx.doi.org/10.1590/1519-6984.20613. PMid:26465727.

Sanches EG. Rearing of mutton snapper Lutjanus analis subjected to diferent diets. Bioikos (Campinas) 2011; 25(1): 33-40. 